\title{
Forcing mechanisms of a heavy precipitation event in the southeastern Adriatic area
}

\author{
Branka Ivančan-Picek • Kristian Horvath • Nataša Strelec Mahović • \\ Marjana Gajić-Čapka
}

Received: 26 February 2013/Accepted: 23 January 2014/Published online: 12 February 2014

(C) The Author(s) 2014. This article is published with open access at Springerlink.com

\begin{abstract}
The aim of this study was to identify the main mesoscale features and mechanisms responsible for the generation of an extreme precipitation event as a contribution to improving the modelling of processes that produce HPEs. The event occurred during the morning hours on 22 November 2010 over the Dubrovnik coast in Croatia and the hinterland mountain range of the southern Dinaric Alps and caused severe flash floods and landslides and consequent interruption of traffic and electricity supply as well as other infrastructural damage. The analysis is geographically focused on the southern portion of the eastern Adriatic region, which is prone to relatively frequent heavy precipitation events that occur mostly in autumn. This area is one of the rainiest in Europe with expected annual amounts of precipitation greater than $5,000 \mathrm{~mm}$ in the mountainous hinterland. The mechanisms responsible for the formation of convection were analysed using synop measurements, satellite data and numerical experiments performed with the WRF model, which was set up at the convection-permitting resolution in the innermost domain. Satellite data were used to identify the precipitation systems and to estimate the intensity of the precipitation during the period of interest. The development of the precipitation system was connected to a strong large-scale ascent over the southern Italy and southern Adriatic due to the advection of warm air and cyclonic vorticity advection, which increases with height. The numerical simulations highlighted the essential role of a southerly low-level jet stream in the transport of warm and moist air towards the affected area. The convergence of two branches of low-level marine air favoured convection triggered over the coast and sea. Furthermore, numerical sensitivity experiments suggested that the orography of the Dinaric Alps plays an essential role in the precipitation maximum over the mountainous hinterland, but also that the orography was not the crucial factor in the heavy precipitation near Dubrovnik. This study highlights the need for a dense network of observations, especially radar measurements, to validate the simulated mechanisms and improve numerical forecasts via data assimilation.
\end{abstract}

B. Ivančan-Picek $(凹) \cdot$ K. Horvath $\cdot$ N. S. Mahović · M. Gajić-Čapka Meteorological and Hydrological Service, Grič 3, Zagreb, Croatia e-mail: picek@cirus.dhz.hr 
Keywords Heavy precipitation - Mesoscale processes $\cdot$ Low-level convergence

\section{Introduction}

Natural hazards, among which high-impact precipitation events play an important role, can heavily influence the population as well as the infrastructure and economy of the endangered areas. The ability to predict such high-impact events (heavy precipitation and flash flooding) remains weak because of the contribution of fine-scale processes and their nonlinear interactions with the larger-scale processes. Significant amounts of work have been carried out during MEDEX (the Mediterranean Experiment on cyclones that produce high-impact weather in the Mediterranean) and MAP (Meso-scale Alpine Programme), but many uncertainties still remain, and new research is needed in this field (see Bougeault et al. 2001; Jansa et al. 2001a; Buzzi et al. 2005, for a summary).

Along the Mediterranean, research on the occurrence of heavy precipitation events (HPEs) has focused primarily on the western Mediterranean (e.g. Doswell et al. 1998; Buzzi and Foschini 2000; Romero et al. 2000; Jansa et al. 2001a, b; Ducrocq et al. 2008; Nuissier et al. 2008). Although complex, the link between heavy precipitation and synoptic-scale troughs and cyclones was well established in the past. Heavy precipitation occurs preferentially downstream of a cyclone aloft (Doswell et al. 1998), and convection plays an important role in most events in the region. Certain mechanisms acting on the large or mesoscale contribute to destabilising the air mass and enhancing convection. The synoptic environment that supports the localised and heavy rainfall is characterised by southerly to easterly low-level flow that transports the moist and unstable Mediterranean air masses towards the coast. Additionally, at low levels, a long fetch of flow over the Mediterranean Sea interacts with terrain features, thus driving local low-level circulation favourable to triggering of deep convection and enhancement of precipitation.

Heavy precipitation also can be observed in the Mediterranean region without any significant cyclone development in the vicinity of the areas affected by precipitation (e.g. Jansa et al. 2001b; Turato et al. 2004). Climatologically, the rainfall is mostly concentrated over slopes exposed to air masses originating from the western Mediterranean or the Adriatic Sea (Frei and Schär 1998). The seasonal distribution of HPEs in the Mediterranean (with the maximum occurring in late summer and during autumn) suggests the relevant role of the Mediterranean Sea high sea surface temperature (SST) during this period of the year, which allows extensive water vapour loading of the atmospheric lower layer. Combined with the northern upper-level cold air masses that progress towards the region during this period of year, warm and wet Mediterranean air masses become conditionally unstable. However, past studies have shown that for most of the HPEs, large amounts of moisture are required to feed the precipitation system. Focusing on the 2000 Piedmont flood event, Turato et al. (2004) reported that only $20 \%$ of the moisture originated from local Mediterranean sources. The main source for this HPE appeared to be the eastern Atlantic.

The Adriatic Sea is a northwest-southeast elongated basin in the central Mediterranean sea, approximately $200 \mathrm{~km}$ wide and 1,200 km long and is almost entirely enclosed by mountains, namely the Apennines to the west and southwest, the Alps to the north and the Dinaric Alps to the east and southeast. These topographic features play a large role in the structure and evolution of the weather systems associated with heavy precipitation. 
Research on HPE occurrence in the wider Adriatic region has focused primarily on the northern Adriatic and southeastern slopes of the Alps (e.g. Vrhovec et al. 2001; IvančanPicek et al. 2003; Kozarić and Ivančan-Picek 2006; Tudor et al. 2011b). Cyclonic activity in the Adriatic and the central Mediterranean provides a triggering mechanism for a range of extreme weather phenomena, such as local downslope windstorm bora (or bura in Croatia) (e.g. Grisogono and Belušić 2009), strong southeasterly sirocco or jugo wind (Jurčec et al. 1996), heavy precipitation and mesoscale convective systems (Gajić-Čapka and Ivančan-Picek 2000; Ivančan-Picek et al. 2003). The spatial distribution of the frequency of cyclogenesis in the Mediterranean shows one of the maxima in the Adriatic (Trigo et al. 1999; Campins et al. 2000, 2006). As reported in the high-resolution climatology study by Horvath et al. (2008), two mesoscale cyclonic areas are found in the Adriatic Sea, and four general types of cyclones affect the region.

Very wet days (R95) ${ }^{1}$ with precipitation amounts greater than $41 \mathrm{~mm}$ (according to Dubrovnik data) are occasional but typical features for the South Adriatic and wider Dubrovnik region (Gajić-Čapka 2010). The complex orographic structure in this area favours the lifting of low-level unstable air and initiation of the condensation processes. These systems produce heavy short-term precipitation with annual maxima that mostly occur in the period from August to November for durations up to $2 \mathrm{~h}$ (Table 1). This observation is in agreement with the results obtained by Mikuš et al. (2012). Based on lightning measurements used as a tracer of vigorous convection, this group found that the convective activity over the coastal region of Croatia is more pronounced in the autumn. The southwesterly upper-level flow represents the most common flow regime on days with convective activity.

The current study examines the mesoscale causes of intensification of the extreme precipitation event that occurred during the morning hours on 22 November 2010 over the Dubrovnik coast and the hinterland mountain range of the southern Dinaric Alps. This event caused severe flash floods, landslides, interruption of traffic and electricity supply and other infrastructural damage with costs greater than 25 million EUR. The aim of this study was to identify the main mesoscale features and mechanisms responsible for the generation of this HPE in the southern Adriatic area as a contribution to progress on the predictability of intense events, specifically by improving the modelling of processes that produce HPEs.

The remainder of this paper is organised as follows. An assessment of the extremity of this rain episode is presented in Sect. 2. Section 3 analyses the observations available for the case. Section 4 presents the mesoscale features leading to heavy precipitation, and the results and conclusions are given in Sect. 5.

\section{Precipitation climatology and extreme value analysis of short-term precipitation maxima}

The eastern Adriatic coastal region experiences two climatic maxima of the annual precipitation (Fig. 1). Annual amounts of precipitation greater than 3,000 $\mathrm{mm}$ on average can be expected in the Croatian mountainous district of Gorski kotar and on Mount Velebit (the Dinaric Alps), which have elevations of up to 1,600 $\mathrm{m}$ and are located close to the Adriatic

\footnotetext{
${ }^{1}$ Number of days with precipitation $R_{\mathrm{d}}>R_{95 \%}$, where $R_{95 \%}$ is the 95 th percentile of the distribution of daily precipitation amounts at days with $1 \mathrm{~mm}$ or more precipitation in the 1961-1990 baseline period (WMO 2004).
} 
Table 1 Frequency $(\%)$ of annual precipitation maxima in different intervals throughout the year at Dubrovnik (period 1959-2009)

\begin{tabular}{lllllllllllll}
\hline Intervals & J & F & M & A & M & J & J & A & S & O & N & D \\
\hline $10 \mathrm{~min}$ & 0 & 3 & 0 & 0 & 5 & 14 & 3 & 27 & 14 & 22 & 11 & 3 \\
$20 \mathrm{~min}$ & 0 & 3 & 0 & 0 & 5 & 11 & 5 & 32 & 14 & 19 & 11 & 0 \\
$30 \mathrm{~min}$ & 0 & 3 & 0 & 0 & 3 & 11 & 5 & 30 & 19 & 19 & 11 & 0 \\
$40 \mathrm{~min}$ & 0 & 3 & 0 & 0 & 0 & 11 & 8 & 32 & 19 & 19 & 8 & 0 \\
$50 \mathrm{~min}$ & 3 & 3 & 0 & 0 & 0 & 11 & 8 & 32 & 16 & 16 & 11 & 0 \\
$60 \mathrm{~min}$ & 3 & 5 & 0 & 0 & 0 & 8 & 5 & 35 & 16 & 16 & 11 & 0 \\
$2 \mathrm{~h}$ & 3 & 5 & 0 & 0 & 3 & 3 & 5 & 32 & 19 & 14 & 16 & 0 \\
$4 \mathrm{~h}$ & 0 & 8 & 3 & 0 & 0 & 0 & 5 & 32 & 22 & 11 & 16 & 3 \\
$6 \mathrm{~h}$ & 0 & 8 & 3 & 0 & 3 & 0 & 5 & 32 & 19 & 11 & 16 & 3 \\
$12 \mathrm{~h}$ & 0 & 11 & 3 & 0 & 3 & 0 & 5 & 24 & 22 & 11 & 16 & 5 \\
$18 \mathrm{~h}$ & 0 & 11 & 3 & 0 & 0 & 0 & 3 & 22 & 16 & 19 & 19 & 8 \\
$24 \mathrm{~h}$ & 0 & 11 & 5 & 3 & 0 & 0 & 3 & 22 & 11 & 19 & 19 & 8 \\
\hline
\end{tabular}

coast (Zaninović et al. 2008). The second annual precipitation maximum appears in the mountainous hinterland of the southern portion of the eastern Adriatic coast. Due to the proximity of the complex orography of Montenegrin mountains (Krivošije) to the Dubrovnik coastal region, notably large spatial gradients occur in the climatological precipitation amounts (Gajić-Čapka 2010). The average annual precipitation ranges from approximately $600 \mathrm{~mm}$ over the Dalmatian islands to greater than $5,000 \mathrm{~mm}$ in southeastern Montenegro (Magaš 2002). The climatological maxima in southeastern Montenegro occur on the mountain summits (Orjen, over 5,000 mm; Crkvice, 4,926 $\mathrm{mm}$ at a height of $940 \mathrm{~m}$; Radoičić, up to $5,155 \mathrm{~mm}$ ). This area is one of the rainiest areas in Europe (Ducić et al. 2012; Isotta et al. 2013; Schneider et al. 2013).

On average, approximately $20 \%$ of the annual precipitation total in the Dubrovnik coastal area is due to heavy precipitation that falls on very wet days. These events are more frequent and more intense with increasing distance from the coast and increasing altitude (Gajić-Čapka 2010).

In the morning hours of 22 November 2010, heavy precipitation reached the Dubrovnik coast and the hinterland mountain range of the southern Dinaric Alps. A peak intensity of $145.5 \mathrm{~mm}$ was registered in the 4-h period. The rain gauge in Dubrovnik $(H=52 \mathrm{~m}$ asl, $\left.\varphi=42^{\circ} 38^{\prime} \mathrm{N}, \lambda=18^{\circ} 5^{\prime} \mathrm{E}\right)$ measured a daily precipitation amount of $161 \mathrm{~mm}$ on 23 November 2010, which was more than the half of the monthly total.

The precipitation amount that fell between 8 UTC and 12 UTC on 22 November 2010 is shown by the 10-min precipitation data recorded in Dubrovnik (Fig. 2). The most intense component of the rainfall episode occurred during the first $2 \mathrm{~h}$, and the highest hourly peak of $71.5 \mathrm{~mm}$ was recorded at $10 \mathrm{UTC}$.

Prior to the mesoscale analysis, the recorded precipitation data for different intervals throughout the observed heavy precipitation event on 22 November 2010 were subjected to an extremity assessment using extreme value analysis (Jenkinson 1969; Faragó and Katz 1990; Coles 2001). The measured rainfall amounts at the Dubrovnik meteorological station were compared with the expected annual precipitation maxima for different return periods estimated according to the generalised extreme value (GEV) distribution based on the long-term data series. The general solution is given in the form: 


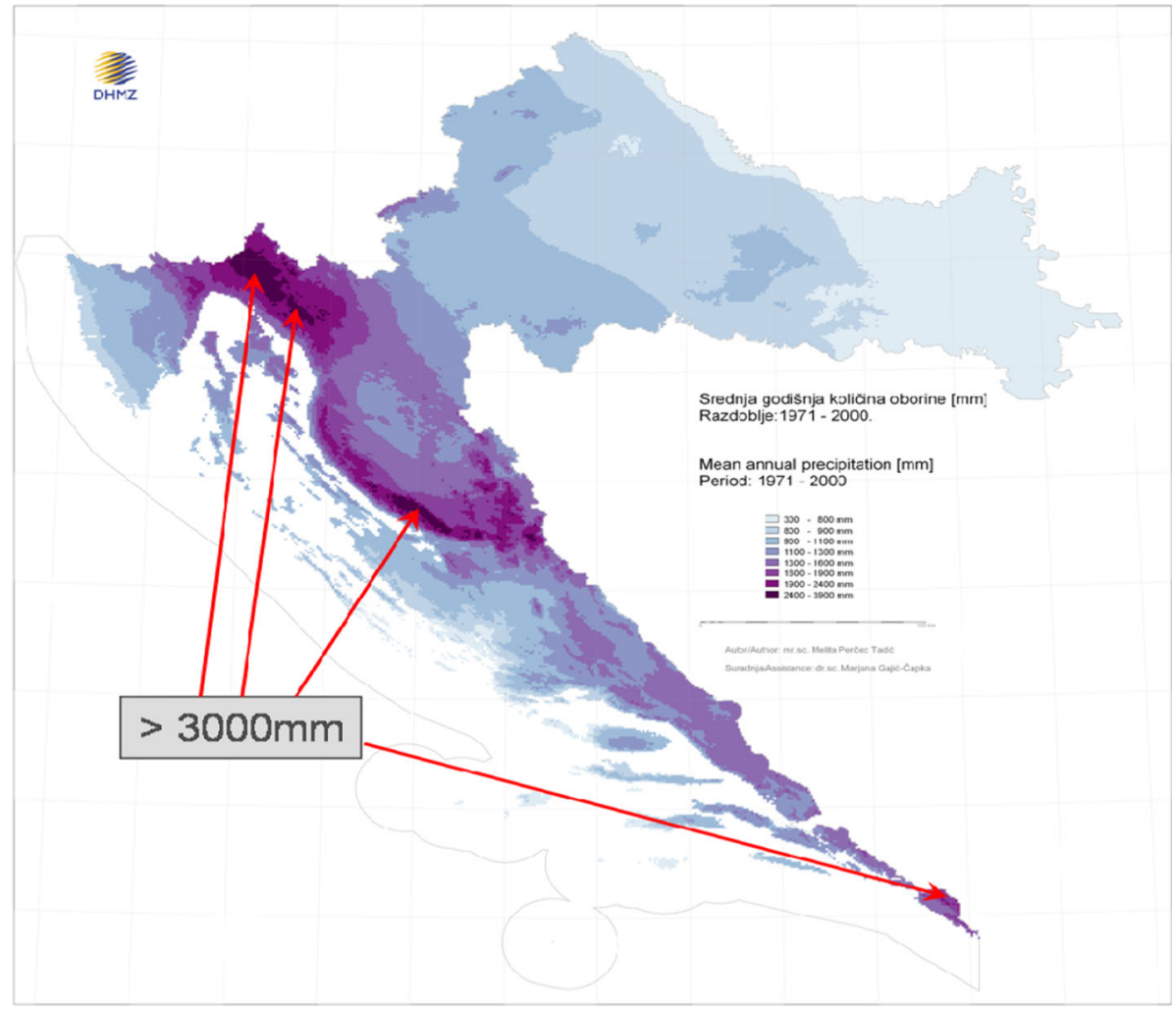

Fig. 1 Mean annual precipitation for Croatia during the period 1971-2000

$$
x=x_{0}+\alpha \frac{1-e^{-k y}}{k}
$$

The maximum values $x$ are related to return period $T$ by means of reduced variate $y$ :

$$
y=-\ln \ln T /(T-1)
$$

where $y$ approximates $\ln (T-0.5)$ and is essentially $\ln T, x_{0}$ is the value expected once a year, $y=0, \alpha$ is the slope of the $x, y$ curve at $y=0$, and $k$ is a curvature parameter yielding three distribution types for negative, zero and positive $k$.

For the intervals of 10, 20,30,40, 50 and $60 \mathrm{~min}$ and 2, 4, 6 and $12 \mathrm{~h}$, the data were taken from the period 1959-2009, and for the durations of 18 and $24 \mathrm{~h}$, the data were taken from the period 1971-2009.

The highest amounts recorded in short-term intervals up to 40 min could be expected once in less than 10 years, and those in the intervals of 50 and 60 min could be expected once in 17 and 25 years, respectively (Table 2; Fig. 3). These maxima were all less than the absolute annual values recorded in the period 1959-2009. However, the highest amounts that belong to the longer-term intervals of 2-18 h exceeded the absolute annual maxima recorded since 1959. These values could be expected quite rarely, with a probability of exceedance of $<1.4 \%$. Their return periods range from approximately 70 years (for the 6-h maximum) to 160 years (for the 4-h maximum). 


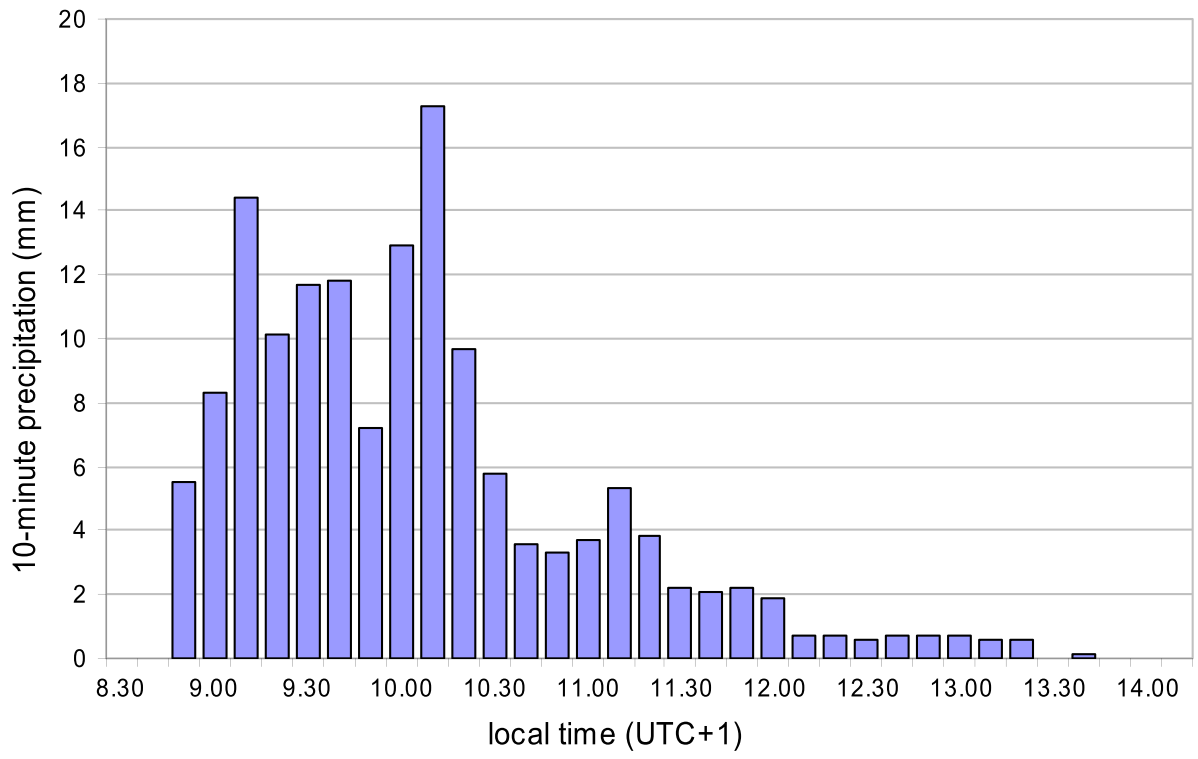

Fig. 2 The 10-min precipitation amounts on 22 November 2010 recorded at the Dubrovnik meteorological station

Table 2 Annual maximal precipitation amounts $\left(R_{\max }\right)$ recorded in different intervals $t$ (min) throughout the period 1959-2009 (*1971-2009) during the heavy rainfall event on 22 November 2010 at Dubrovnik and their return periods $(T)$ according to the GEV distribution

\begin{tabular}{|c|c|c|c|c|}
\hline \multirow[t]{2}{*}{$t(\min )$} & \multicolumn{2}{|l|}{ 1959-2009 } & \multicolumn{2}{|l|}{2010} \\
\hline & $R_{\max }(\mathrm{mm})$ & $T$ (year) & $R_{\max }(\mathrm{mm})$ & $T$ (year) \\
\hline $10 \mathrm{~min}$ & 29.6 & 106.8 & 17.3 & 2.9 \\
\hline $20 \mathrm{~min}$ & 49.4 & 73.5 & 30.9 & 6.1 \\
\hline $30 \mathrm{~min}$ & 69.1 & 114.5 & 40.2 & 7.2 \\
\hline $40 \mathrm{~min}$ & 87.4 & 159.1 & 49.2 & 9.4 \\
\hline $50 \mathrm{~min}$ & 98.7 & 141.5 & 63.1 & 17.2 \\
\hline $60 \mathrm{~min}$ & 103.3 & 137.9 & 71.5 & 24.6 \\
\hline $120 \mathrm{~min}$ & 110.8 & 66.5 & 118.3 & 89.5 \\
\hline $240 \mathrm{~min}$ & 110.8 & 36.1 & 145.5 & 161.5 \\
\hline $360 \mathrm{~min}$ & 126.4 & 33.0 & 148.2 & 68.8 \\
\hline $12 \mathrm{~h}$ & 133.1 & 39.7 & 149.0 & 108.0 \\
\hline $18 \mathrm{~h}^{*}$ & 148.4 & 35.8 & 150.7 & 53.5 \\
\hline $24 \mathrm{~h} *$ & 165.0 & 37.4 & 152.6 & 23.9 \\
\hline
\end{tabular}

\section{Case overview}

\subsection{Observational analysis}

Meteorological products derived from satellite data were used to identify the precipitation systems and estimate the intensity of the precipitation during the period of interest. The 
Fig. 3 Estimates of annual precipitation maxima according to the GEV distribution (lines) and empirical data distributions (rhombus) for different intervals in the period 1959-2009 for Dubrovnik. The circles represent maximal precipitation amounts during the heavy rainfall event on 22 November 2010

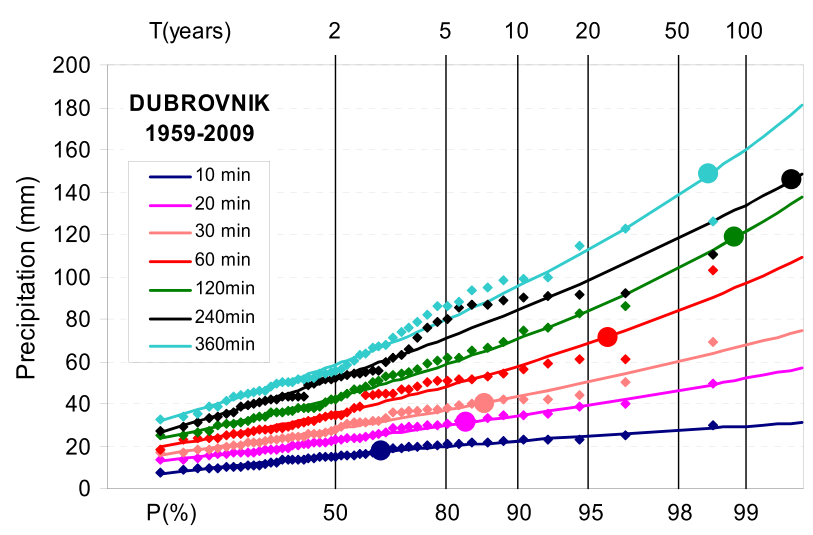

analysis of these products provided valuable information, especially over the sea where no other observations (surface or radar data) were available.

The Convective Rainfall Rate (CRR) product, derived from the algorithm developed within the Satellite Application Facility with support to Nowcasting (SAF NWC) and Very Short-Range Forecasting, (http://www.nwcsaf.org/HTMLContributions/SUM/SAF-NWCCDOP-INM-SCI-ATBD-05_v3.1.1.pdf), estimates the rainfall rates of convective systems using the 10.8- and 6.2- $\mu \mathrm{m}$ Meteosat Second Generation (MSG) Spinning Enhanced Visible and Infrared Imager (SEVIRI) channels at night, and during the daytime, the 0.6- $\mu \mathrm{m}$ channel is added to the algorithm. The CRR algorithm is based on the assumption that the higher and thicker the clouds, the greater the probability of precipitation occurrence and its intensity. In the regions where radar data are available, the CRR is calibrated using calibration matrices generated from both SEVIRI and radar data. Therefore, the CRR can be compared with the precipitation rates measured by the radar, which was especially important in this case because of the lack of radar data over the east Adriatic coast and the Adriatic Sea. The CRR product is derived from each Meteosat 9 scan at intervals of every $15 \mathrm{~min}$. From $0530 \mathrm{UTC}$ on, the hourly rainfall rates were greater than $10 \mathrm{~mm} / \mathrm{h}$, whereas in several timesteps, the rainfall rate was between 30 and $50 \mathrm{~mm} / \mathrm{h}$ over the land (Fig. 4).

From the image in Fig. 4a, which shows the instantaneous convective rainfall rate at 0945 UTC, it is evident that the rainfall rate in the Dubrovnik region was between 30 and $50 \mathrm{~mm} / \mathrm{h}$, whereas on the border with Montenegro, it exceeded $50 \mathrm{~mm} / \mathrm{h}$. These precipitation rates correspond to the maximum measured rainfall rate of $71.5 \mathrm{~mm} / \mathrm{h}$ in Dubrovnik. Over the sea, the rainfall rates were lower than over the land but still exceeded $20 \mathrm{~mm} / \mathrm{h}$ during certain time steps. The rainfall rate in the Dubrovnik area remained notably high until $1215 \mathrm{UTC}$, reaching up to $50 \mathrm{~mm} / \mathrm{h}$ in certain pixels, but at that time, the rain was already concentrated over the land with only low rainfall rates over the sea (Fig. 4b).

Sounding data measured at Zadar Zemunik ( $H=88 \mathrm{~m}$ asl, $\left.\varphi=44^{\circ} 5^{\prime} \mathrm{N}, \lambda=15^{\circ} 21^{\prime} \mathrm{E}\right)$, located approximately $200 \mathrm{~km}$ northwest of the area where the largest rainfall was recorded, provided information on the vertical structure of the troposphere. Although the thermodynamic profile characteristics are not completely representative of the pre-convective environment over the study area, this is the only available sounding data on the eastern Adriatic. Figure 5 shows the Zadar Zemunik sounding taken at 00 UTC 22 November. The sounding depicts an unstable atmosphere because the convective available potential energy (CAPE) was near $304 \mathrm{~J} / \mathrm{kg}$ for an air parcel near the ground. The sounding featured a deep and moist atmospheric layer from the surface to approximately $450 \mathrm{hPa}$ 
(a)

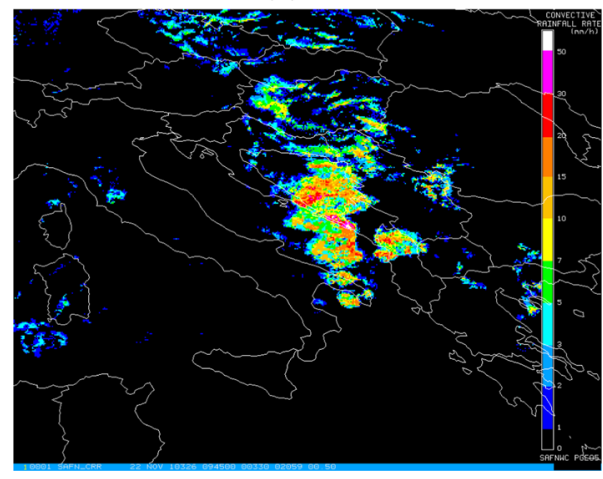

(b)

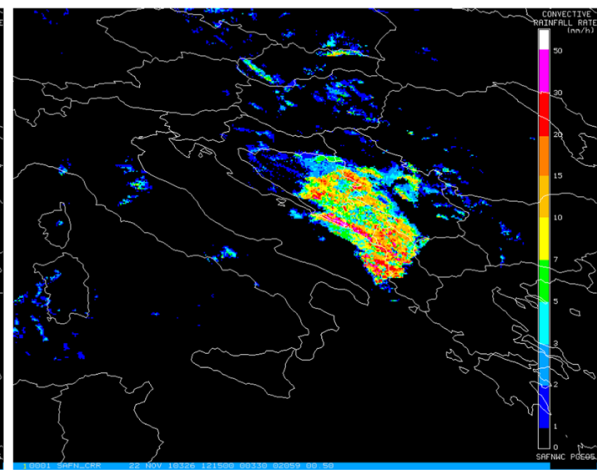

Fig. 4 Convective rainfall rate based on Meteosat-9 data: a 0945 UTC on 22 November 2010, b 1215 UTC on 22 November 2010. Colours denote values in $\mathrm{mm} / \mathrm{h}$ according to the scale

with a dryer layer observed between 650 and $550 \mathrm{hPa}$. In addition, precipitable water exceeding $25 \mathrm{~mm}$ highlights the role of the mid-tropospheric southwesterly circulation in advecting moisture towards the Adriatic region. The winds strengthened throughout the troposphere, and the highest intensity was observed at $300 \mathrm{hPa}$. Strong southwesterly shear of approximately $20 \mathrm{~m} / \mathrm{s}$ in the first $2 \mathrm{~km}$ of the troposphere was also present over this area.

\subsection{Analysis of synoptic patterns}

In investigating the strong precipitation processes over the southern (Buzzi and Foschini 2000) and southeastern Alps (Vrhovec et al. 2001; Ivančan-Picek et al. 2003; Ivatek-Šahdan and Ivančan-Picek 2006), it was found that the following features are important: (1) a deep upper-level trough extending southwards from Scandinavia to the Mediterranean, often accompanied by the development of a Mediterranean cyclone; (2) a flow at low levels that maintains a southerly direction over the Mediterranean with a prefrontal and notably moist southeasterly/southwesterly air flowing over the Adriatic and (3) steep mountain ridges of the southeastern Alps and the Dinaric Alps that aid in releasing the conditional instability. Some of these characteristics are also found in the South Adriatic case.

The primary convective activities took place between 06 and 12 UTC on 22 November 2010. The observational data relate precipitation to the various processes that contributed to the development. The synoptic environment was characterised by a deep cut-off low moving from northern Europe over the Alps and the western Mediterranean, where a surface cyclone developed (Tudor et al. 2011a). The associated frontal system covered most of central Europe and the mid-Mediterranean. During the passage of the cold front over southern Italy and the Adriatic Sea, a secondary cyclone developed, and a mesoscale convective system grew within.

Based on the investigations of different cyclone types in the region and an assessment of associated extreme weather, including heavy precipitation and severe local wind (Horvath et al. 2008), this case could be classified as type AB or simultaneous Genoa and Adriatic cyclones.

Two upper-level jets are observed approaching the southern Adriatic area from west and southwest (dark stripes in the WV 6.2- $\mu \mathrm{m}$ image; Fig. 6). The jet streak at the rear side of 


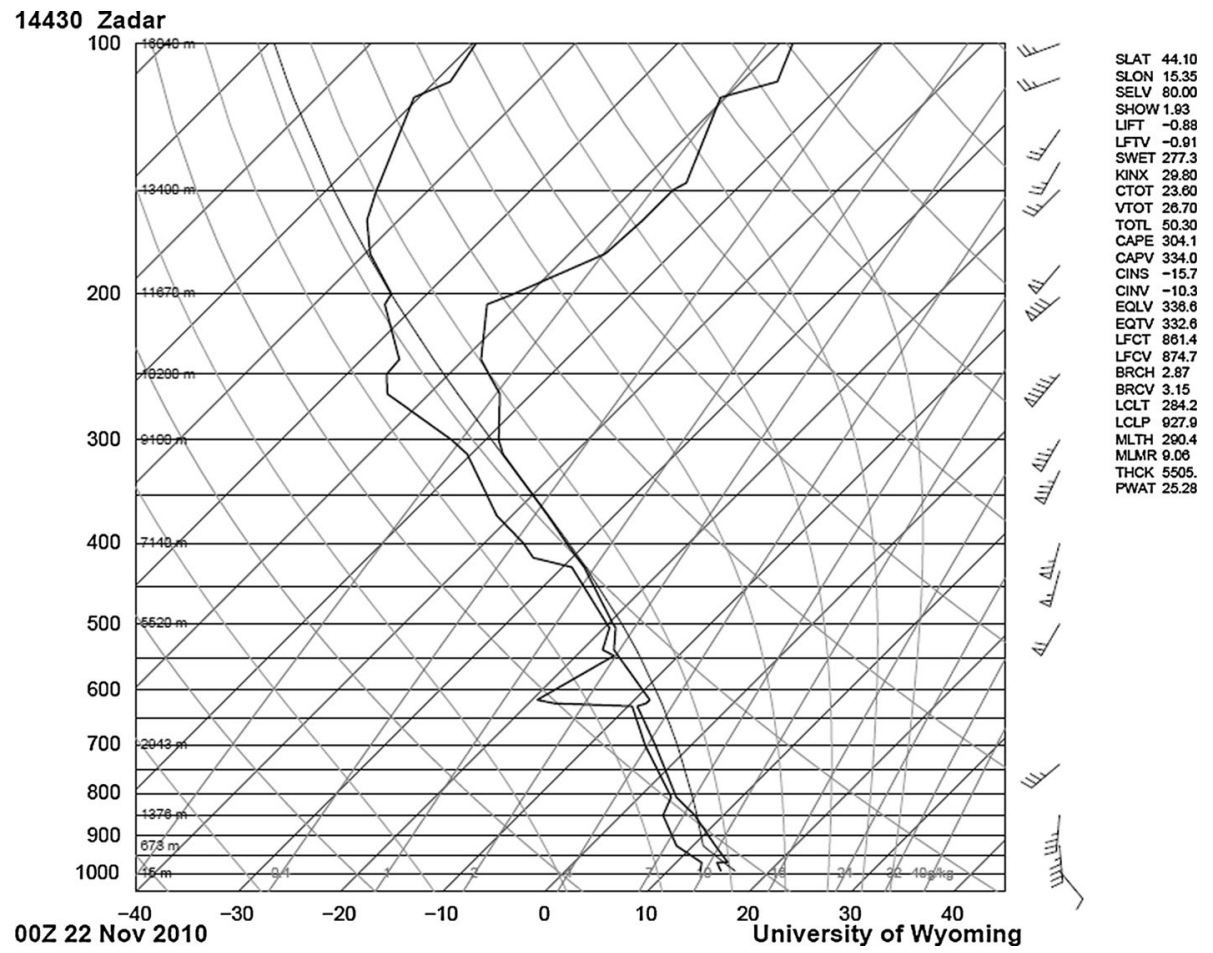

Fig. 5 Skew T-log p-diagram showing thermodynamic sounding observed at 00 UTC on 22 November 2010 in Zadar Zemunik $\left(H=88 \mathrm{~m}\right.$ asl, $\left.\varphi=44^{\circ} 5^{\prime} \mathrm{N}, \lambda=15^{\circ} 21^{\prime} \mathrm{E}\right)$. Source of observed soundings: http:// weather.uwyo.edu/upperair/sounding.html

the cold front crossed the frontal cloud band at a large acute angle, causing the intensification of the process over the mid-Mediterranean.

Satellite data combined with the ECMWF model parameters give additional information on the evolution of this HPE. Figure 7 shows the Meteosat 9 IR 10.8- $\mu \mathrm{m}$ images for 06 and 12 UTC on 22 November 2010 overlaid with the ECMWF field of temperature advection at the 700-hPa level (Fig. 7a, b) and the isotachs for a wind speed $>30 \mathrm{~m} / \mathrm{s}$ combined with cyclonic (positive) vorticity advection (PVA) isolines at the 500-hPa (red) and $300-\mathrm{hPa}$ (orange) levels (Fig. 7c, d). Two pairs of warm and cold advection maxima are present in the region of interest, one over Central Europe connected to the main centre of the cyclone and the other over the South Adriatic connected to the formation of the secondary low centre. Warm air advection in the lower troposphere is maximised over the South Adriatic (Fig. 7a, b). This area of positive temperature advection overlaps with the upper-level advection of cyclonic vorticity as a consequence of the deepening trough in the neighbourhood of the left exit region of the jet streak (Fig. 7c, d).

Calculation of quasi-geostrophic forcing for vertical motion reveals that the evolution of upper-level positive vorticity and the low-level temperature advection are associated with important centres of dynamic forcing for upward motion in the mid-upper and lower troposphere (Romero 2001). Positive temperature and vorticity advection are associated with notably strong ascending motion over the south of Italy and the South Adriatic. The ascent was the strongest over the South Adriatic and the adjacent mountains in Bosnia and 


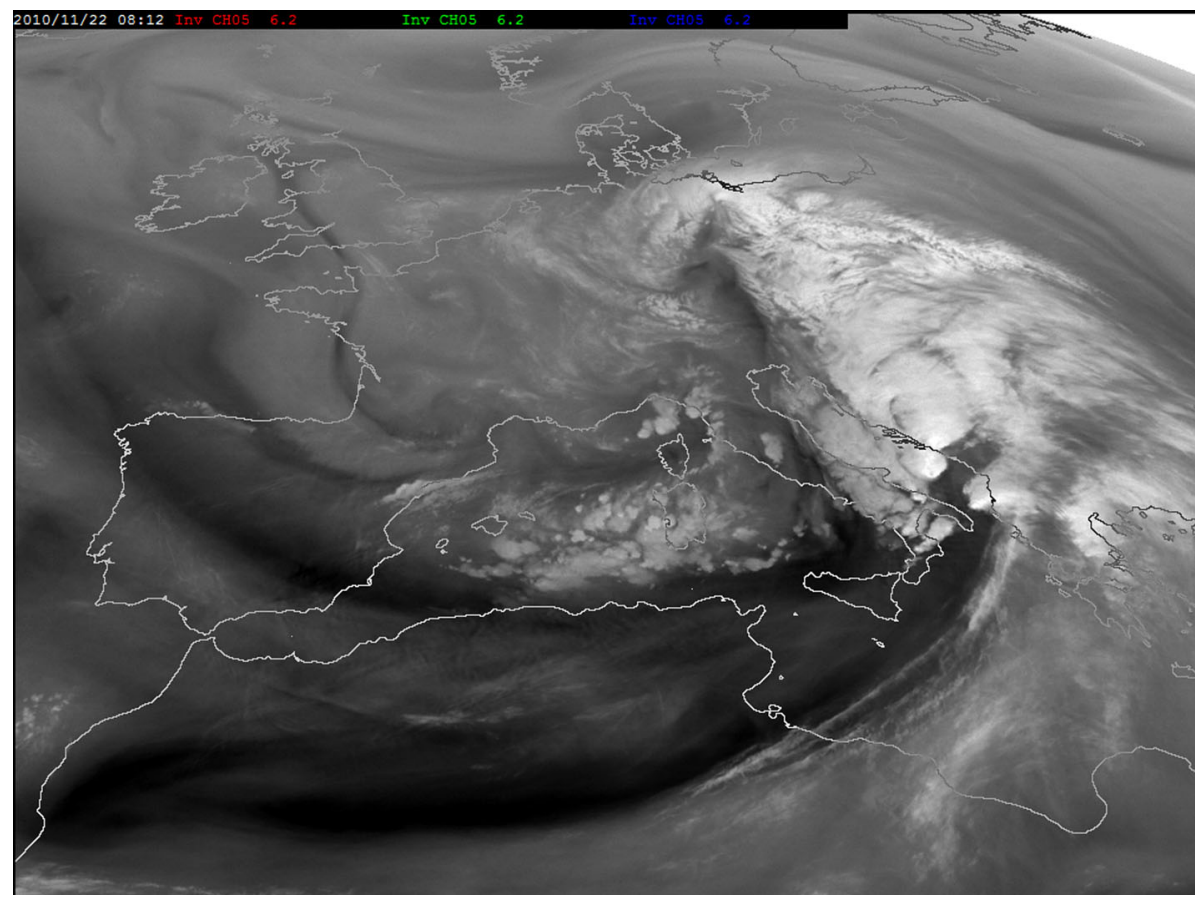

Fig. 6 METEOSAT-9 WV 6.2- $\mu \mathrm{m}$ image at 08 UTC on 22 November 2010

Montenegro, where the strongest development took place (Fig. 8). In the cross-section, along the yellow line marked in Fig. 8b, a region of steeply downward inclined potential temperature isolines (isentropes, black lines in Fig. 8) stretches all the way from the top of the troposphere to the ground. Warmer air found eastwards of that zone, in the right-hand region of the cross-section, ascends along the isentropes above the pool of colder air found to the left (northwestward) of the zone of steeply sloped isentropes. This situation results in rather strong upward motion present from the surface throughout the entire troposphere, up to $300 \mathrm{hPa}$, and is shown by high values of vertical velocity (cyan lines), indicating a notably strong process (Fig. 9). The location of the strongest upward motion in the crosssection coincides with the region of the strongest cloud development observed in Fig. 7.

\section{Mesoscale features}

\subsection{Numerical model setup}

In the Croatian Meteorological and Hydrological Service, the numerical weather prediction model ALADIN/HR runs operationally at 00 UTC and 12 UTC with 8-km horizontal resolution using the 72-h integration of the ALADIN full physics package. The model forecasted large 24-h accumulated rainfall amounts in the broader Dubrovnik area, with maxima of over $100 \mathrm{~mm}$ in Montenegro and in Bosnia and Hercegovina (Tudor et al. 2011a). However, the peak intensity of precipitation in the model runs was both underestimated and late. The imprecise spatial and temporal distribution of precipitation forecast indicates the need for the following: (1) investigation of this event using a higher- 
(a)

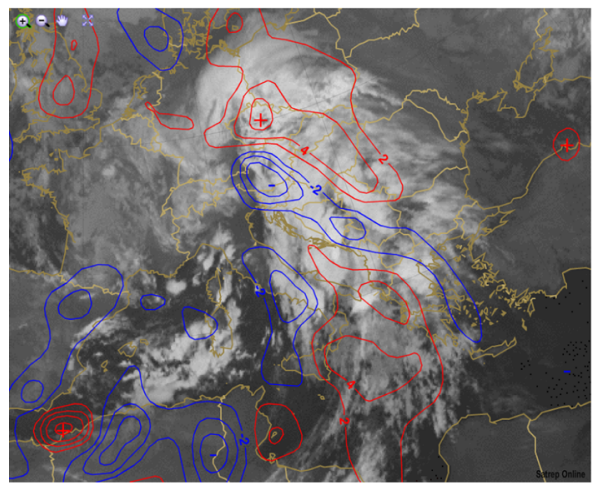

(b)

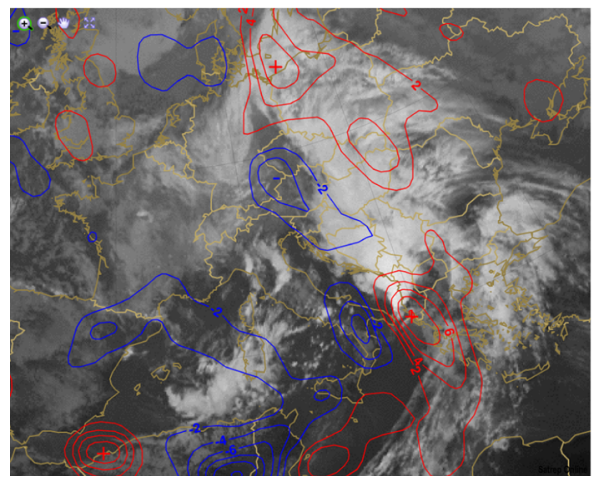

(c)

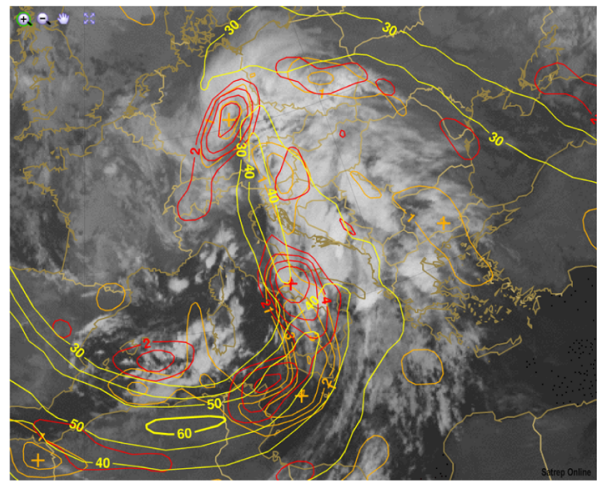

(d)

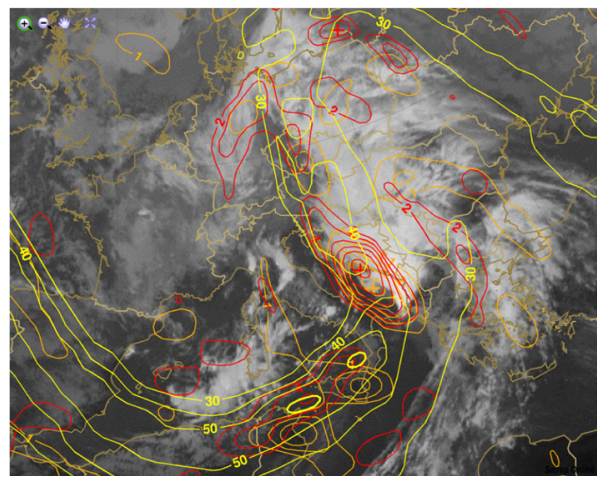

Fig. 7 METEOSAT-9 IR 10.8- $\mu \mathrm{m}$ image overlaid with 700-hPa level temperature advection [positive (warm) advection—red lines and negative (cold) advection—blue lines] at: a 06 UTC on 22 November 2010 and b 12 UTC on 22 November 2010. The 300-hPa wind speed (yellow lines) and positive (cyclonic) vorticity advection at $500 \mathrm{hPa}$ (orange lines) and $300 \mathrm{hPa}$ (red lines) at: c $06 \mathrm{UTC}$ on 22 November 2010 and d 12 UTC on 22 November 2010

(a)

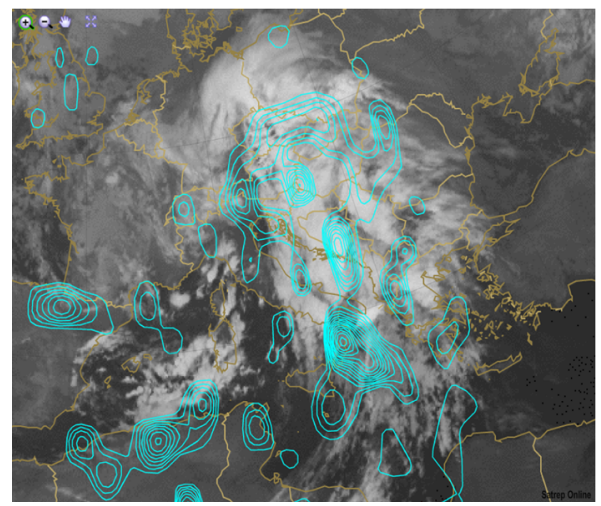

(b)

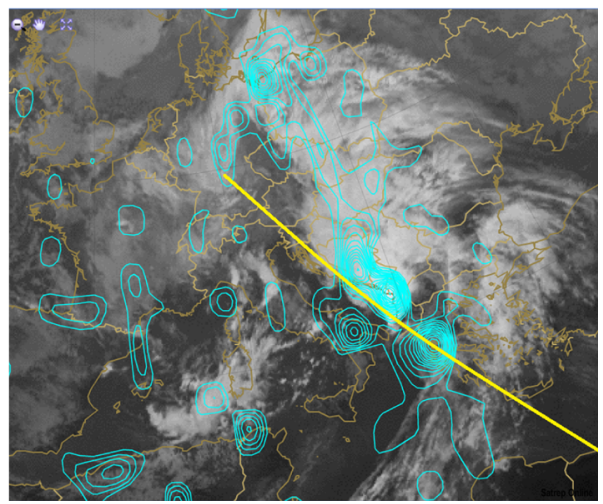

Fig. 8 Vertical velocity $\omega$ at $700 \mathrm{hPa}$ at $06 \mathrm{UTC}$ a and $12 \mathrm{UTC} \mathbf{b}$ on 22 November 2010. The yellow line in Fig. $8 \mathrm{~b}$ marks the location of the cross-section in Fig. 9 


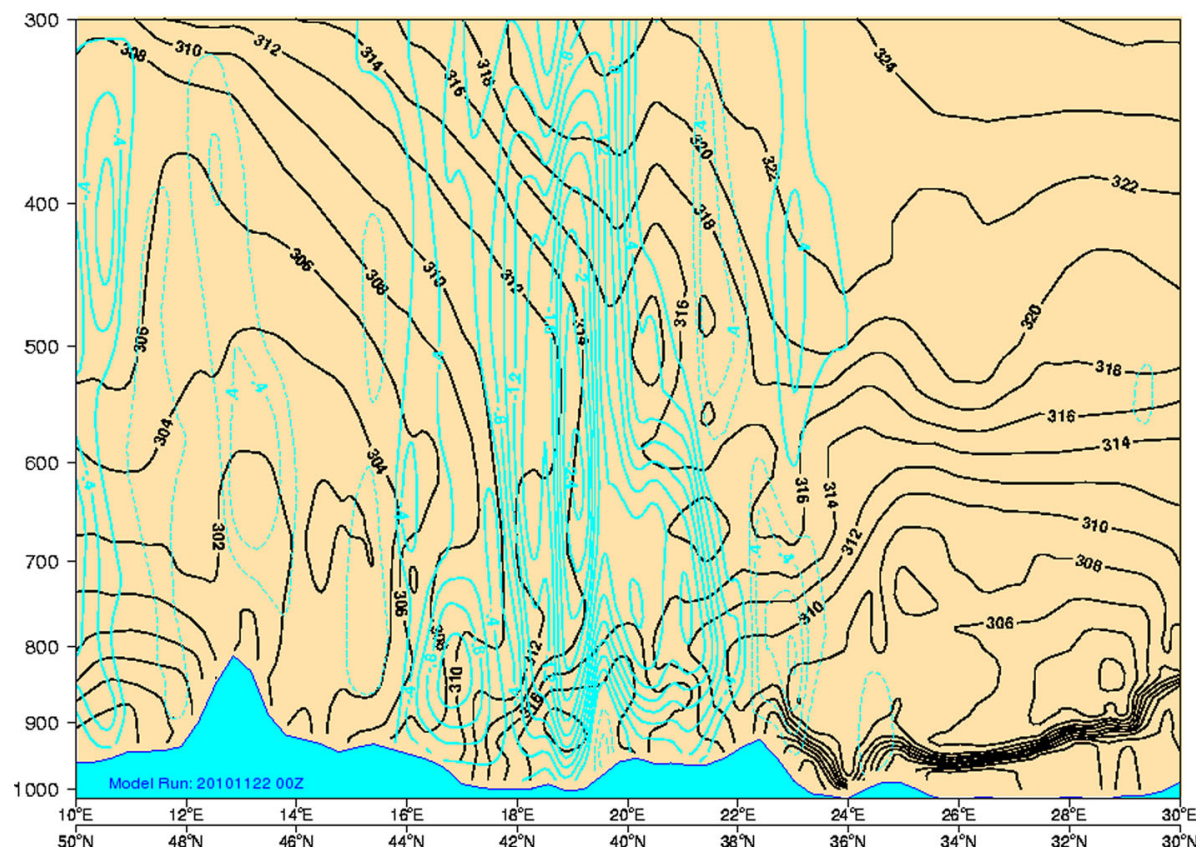

Fig. 9 Vertical cross-section along the line marked yellow in Fig. 8b: potential temperature isolines (black lines) and vertical velocity $\omega$ (blue lines) at 12 UTC on 22 November 2010

resolution mesoscale model with a more advanced set of physical parameterisations and (2) radar and other high-resolution observation data assimilation to produce detailed initial conditions that should result in more realistic HPE forecasts.

Therefore, especially because the southern Adriatic area lacks radar observations, it is necessary to investigate HPE with a high-resolution mesoscale model. To assess the roles of mesoscale low-level environment and the complex orography as well as to study the upper-level dynamics leading to HPEs, we used the mass-core Advanced Research version of the Weather Research and Forecasting (WRF) model (Skamarock et al. 2008) set up at the convectionpermitting grid spacing $(2 \mathrm{~km})$ in the innermost domain. The model was constructed in a twoway grid-nesting with 41 vertical terrain-following pressure levels, including the following physical parameterisations: (1) the Mellor-Yamada-Janjic scheme (1.5-order turbulence closure model) to parameterise the turbulence in the planetary boundary layer (Mellor and Yamada 1974, 1982; Janjić 2001); (2) the Betts-Miller-Janjic scheme (dmn1 only) to represent convective processes (based on Betts and Miller 1986); (3) the Eta surface layer scheme following Monin-Obhukov's similarity theory (Janjić 1996) and (4) the Dudhia (1989) scheme for shortwave radiation and the rapid radiative transfer model for long-wave radiation (Mlawer et al. 1997). The applied microphysics scheme is a two-moment Morrison scheme (Morrison et al. 2009). Finally, to simulate the vertical transport of soil moisture and heat, we used the Noah land-surface model (Chen and Dudhia 2001; Ek et al. 2003).

\subsection{Low-level jets and convergence line features}

As highlighted in Sect. 3.2, the synoptic environment in this HPE was characterised by a deep cut-off low moving from the northern Europe over the Alps and the western 

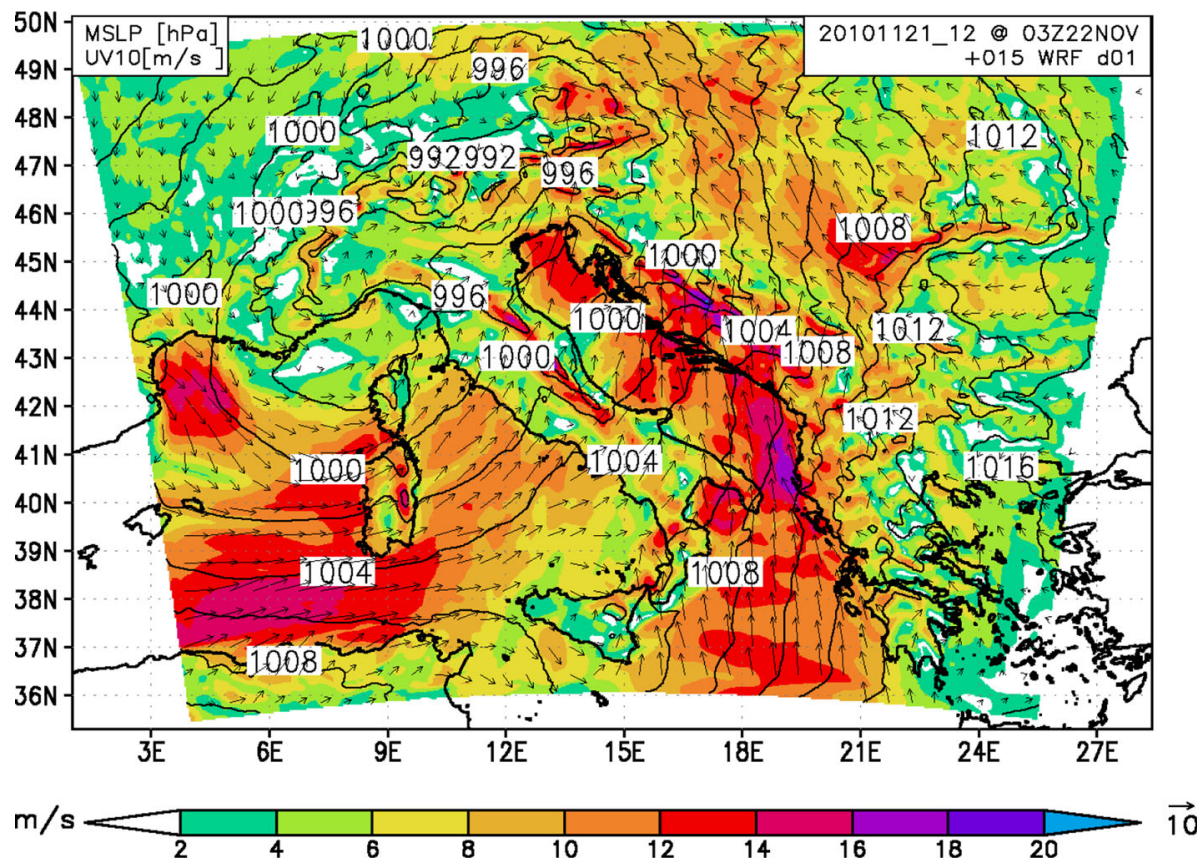

Fig. 10 WRF model of sea level pressure (solid line, 2-hPa interval), wind vectors and wind speed (shaded as in legend) on 03 UTC 22 November 2010. The area corresponds to the outer model domain (8-km grid spacing)

Mediterranean where the surface Genoa cyclone developed. During the passage of the cold front over the southern Italy and the Adriatic Sea, a secondary shallow low was developed with an embedded mesoscale convective system. Figure 10 shows the sea level pressure, low-level wind vectors and wind speed at 03 UTC on 22 November 2010. The low-level wind field is dominated by two low-level jet stream (LLJS) that carry the warm and humid Mediterranean air to the Adriatic Sea. One SW LLJ associated with the main Genoa cyclone was elongated from Italy towards the middle Adriatic, and another S-SE LLJ was observed at the Otranto strait. This situation is favourable for the strong S-SE wind known as the jugo ("jug" means "south" in Croatian).

The connection between cyclonic activity and the severe jugo in the Adriatic is documented in the literature (e.g. Jurčec et al. 1996; Brzović and Strelec Mahović 1999). The jugo is a rather shallow weather phenomenon usually extending no more than $2 \mathrm{~km}$ in height, where it rapidly changes to SW winds on the advanced side of an upper-level trough (Fig. 5). Figure 11 depicts the 2-km resolution model simulation of the low-level wind field in the time frame from 00 UTC to 09 UTC on 22 November when extreme precipitation occurred over the broader Dubrovnik area. The analysis of a low-level wind shows a particular pattern with modification of the jet structure. As the SW LLJ located over the middle Adriatic progressively attenuated, the S-SE LLJ was amplified due to the channelling and blocking effects of the southern Adriatic mountains and the Otranto strait. (e.g. Orlić et al. 1994; Pasarić et al. 2007). This event presented a similar geographical distribution of jugo wind as observed in other studies and reached a wind speed up of to $28 \mathrm{~m} / \mathrm{s}$ over the southeastern portion of the basin. 
(a)

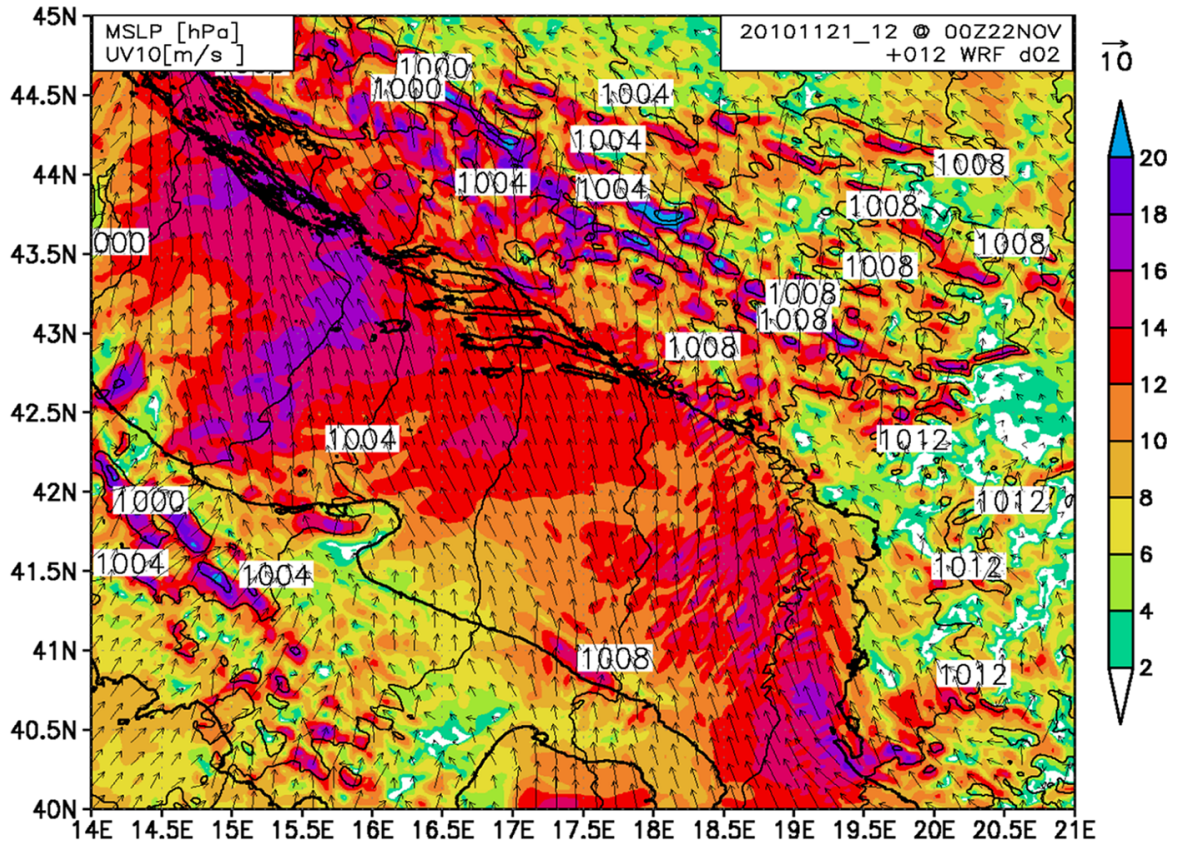

(b)

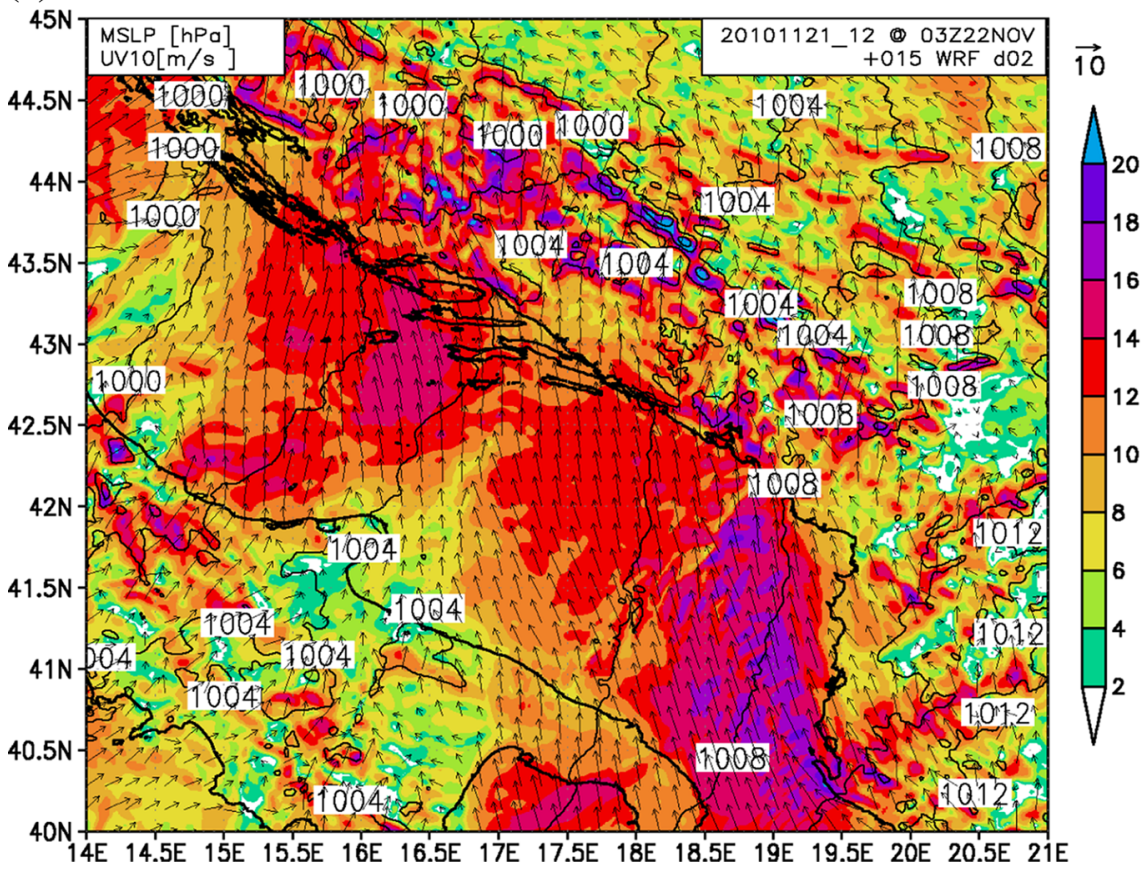

Fig. 11 WRF model of the sea level pressure (solid line, 2-hPa intervals), wind vectors and wind speed (shaded as in legend): a 00 UTC, b 03 UTC, $\mathbf{c} 06$ UTC and d 09 UTC on 22 November 2010. The area corresponds to innermost model domain (2-km grid spacing) 
(c)

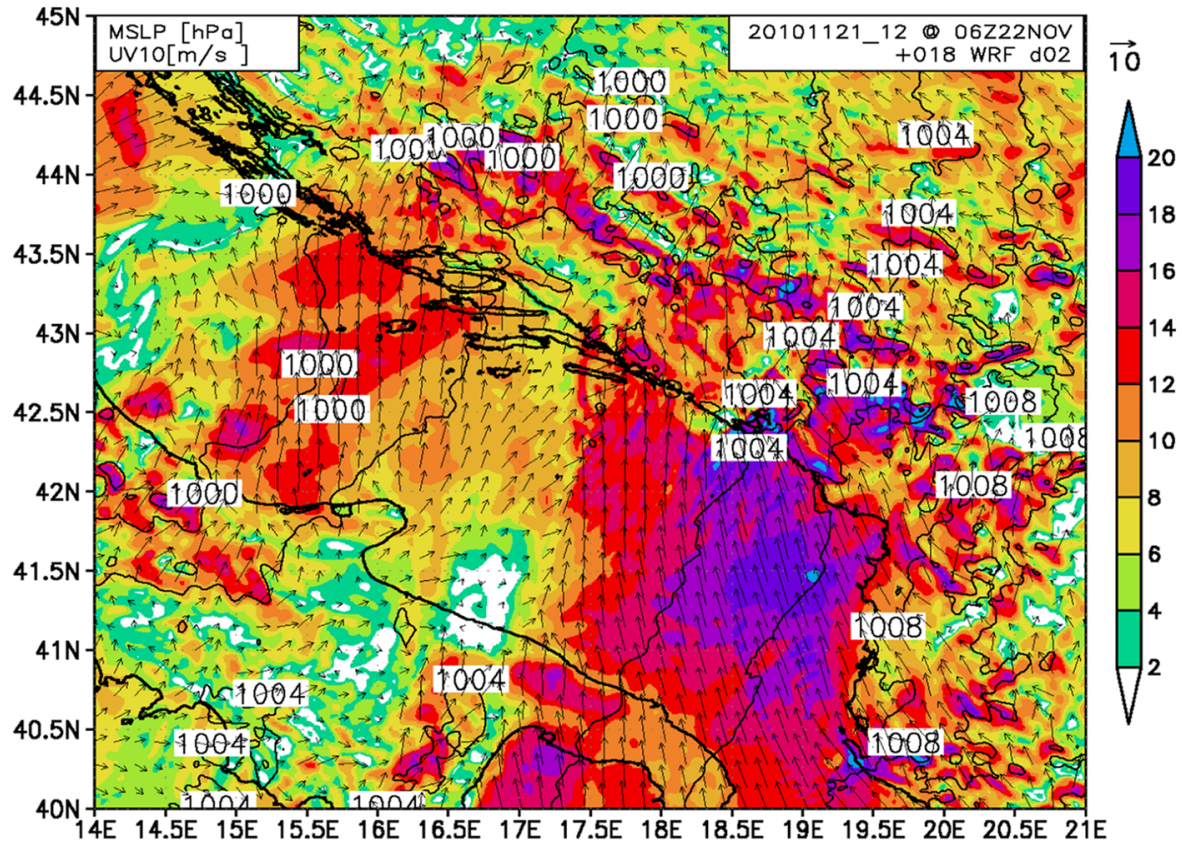
(d)

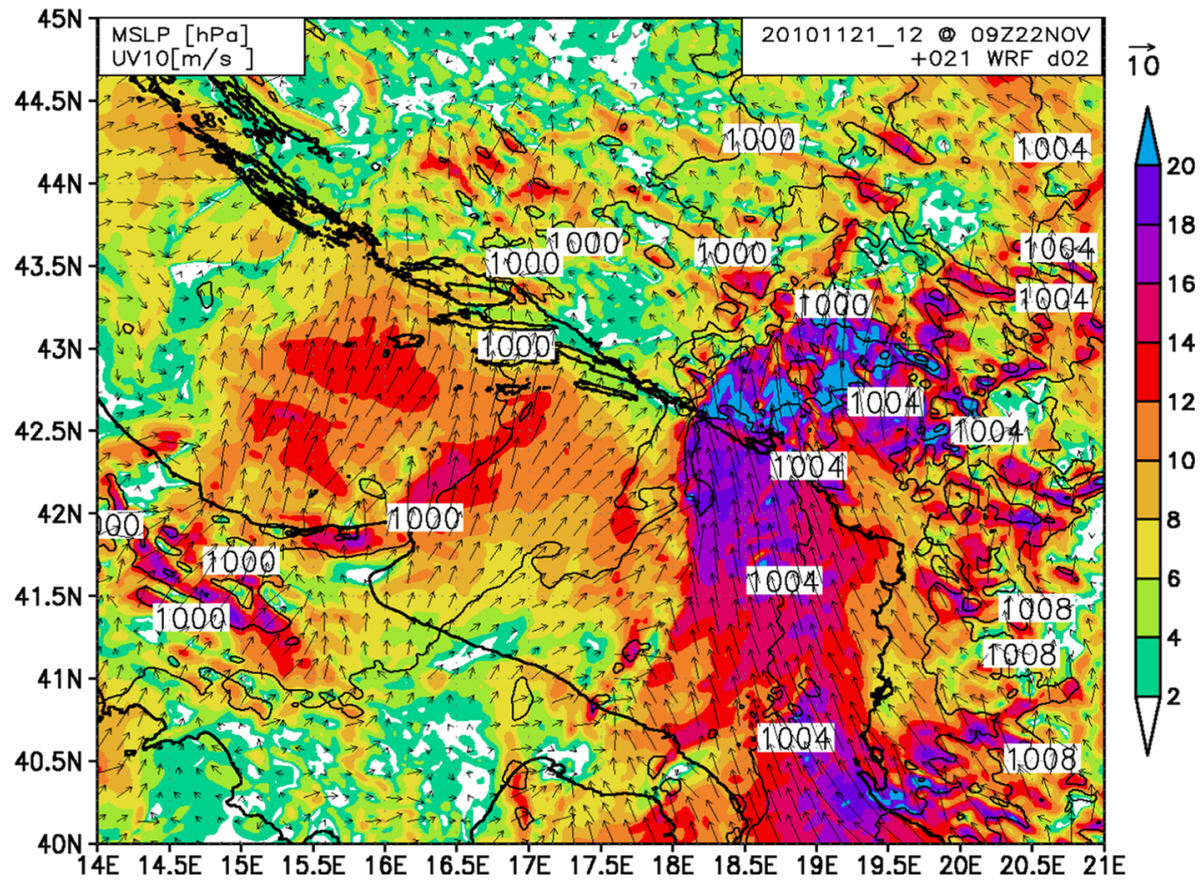

Fig. 11 continued 


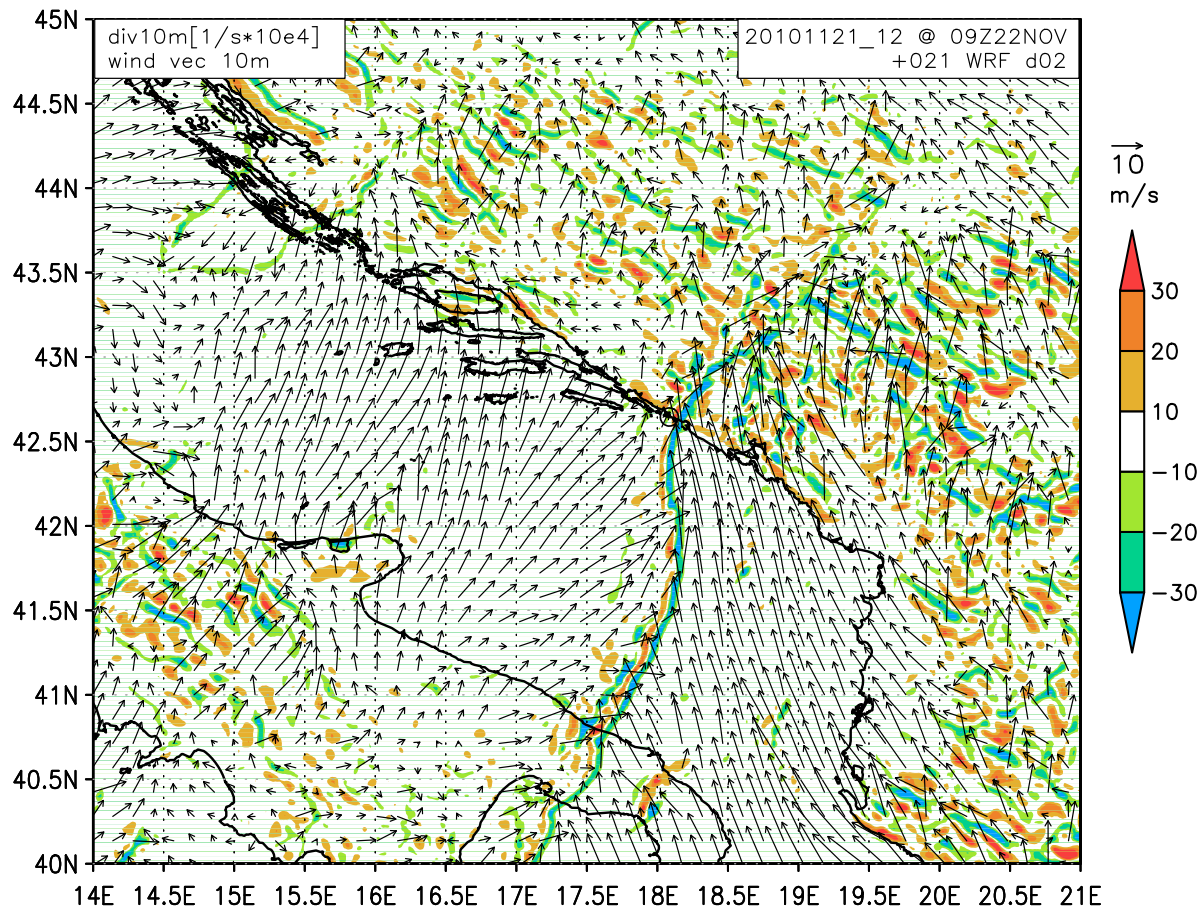

Fig. 12 WRF model of the 850-hPa wind vectors and divergence (shaded as in legend) on 09 UTC 22 November 2010

Numerous studies (e.g. Romero et al. 2000; Pasarić et al. 2007) have noted the role of the nearby mountain ridges in enhancing the low-level jet and/or inducing upwind lowlevel convergence. Ivančan-Picek et al. (2003) showed that these mesoscale wind features contain a pronounced ageostrophic component with small-scale vortices of short duration and a clearly marked convergence zone. In the current case, the mesoscale wind features associated with the presence of two LLJs caused the appearance of the low-level wind convergence over the South Adriatic (Fig. 12). The upslope flow, which is quite moist as a result of a long fetch over the sea (2-m relative humidity over $90 \%$ ), impinges on the coastal orography. Many studies have highlighted the link between the convective rainfall and convergence of the low-level wind (e.g. Crook and Klemp 2000; Buzzi and Foschini 2000; Mastrangelo et al. 2011). Convergence lines can serve as both preconditioning and triggering mechanisms. The observation that convective storms often form along detectable convergence zones has led to certain optimism that initiation of these events could be predicted by operational forecasters. However, it is necessary to determine whether a given convergence line will be able to lift air to the level of free convection and hence generate moist convection. The localised enhancement of vertical wind shear and convergence along pre-existing boundaries can lead to increases in the occurrence of severe weather in these locations (Maddox et al. 1980). The low-level convergence line and the orographic effect in combination with upper-level features favour heavy precipitation (e.g. Miglietta and Buzzi 2001) and may increase the precipitation amount (Ducrocq et al. 2008). Persisting for approximately $4 \mathrm{~h}$ in this case, the convergence line likely contributed to the large precipitation amounts in the southern Adriatic area. 
Convection along the low-level wind convergence is visible in the satellite images. In Fig. 6, which shows the 6.2- $\mu \mathrm{m}$ image at $08 \mathrm{UTC}$, the dark regions are the regions of notably dry air along the jet streams. Advection of dry air in the mid-troposphere above a moist lower layer can be a sign of destabilisation or convective potential. The existence of dry air aloft, also proved by the sounding data (Fig. 5), can enhance the evaporation of precipitation and hence the strength of downdrafts from convection (e.g. Johns and Doswell 1992; Carr and Millard 1985). The two jets converge over the southern Adriatic where the strongest convective development occurs in the left exit region of both jets. During the period from 06 UTC to 12 UTC on 22 November, the S-SE LLJ was stationary (Fig. 11). Therefore, the convergence in the exit region of the LLJ was essential to convective formation.

\subsection{Influence of the South Adriatic orography}

Although much knowledge has been gained on orographic precipitation in recent years, the ability to predict its location and intensity with the desired accuracy remains elusive. The orography plays a highly important role in HPEs, more complex than simply lifting the air on the upwind side (Buzzi and Foschini 2000). To better evaluate the role of the Dinaric Alps over the southern Adriatic in the generation of precipitation, a sensitivity test was performed with and without orography. The orography withheld from simulations corresponds to the northern portion of the Dinaric Alps (roughly north of the Montenegro, the Albanian border), allowing the southern portion of the range to influence the development of the associated low-level jet.

Satellite-based rainfall estimation is used to substitute for the missing radar data. The CRR product (Fig. 4) derived from the MSG data shows that intense precipitation occurred above the sea, but the amounts were the largest over the coast and especially over the mountains in the hinterland. A reference simulation with the WRF model was compared with the available rain-gauge observations, showing that the precipitation pattern and amounts are quite well simulated, whereas the precipitation timing and the location of the maxima are reproduced less successfully (Fig. 13a). The largest amount was simulated in the vicinity of the local orographic peaks, directly exposed to the ascent of warm and humid jugo wind.

When the Dinaric Alps were withheld from the simulation, the rainfall in these areas was weakened and not concentrated above the mountain chain as it was in the real situation (Fig. 13b). The precipitation maxima simulated in the run without orography are smaller than those in the control run, but the highest amounts of precipitation are broadly organised along a line. The latter feature indicates that the orography provides further lifting, which causes local precipitation maxima; however, it does not allow convection to occur on (and likely contributes to maintaining) the low-level convergence line as occurring over the sea. However, the area of Dubrovnik and the hinterlands still received greater than $50 \mathrm{~mm}$ of rain. This result shows that in addition to the orographic lift, other mesoscale factors, i.e. the low-level (moisture) convergence, contributed to the measured precipitation maximum over the Dubrovnik area. The maintenance of a slow-moving convergence line and associated precipitation can lead to high and thus hazardous precipitation amounts.

Therefore, the largest component of the mountain-range-scale precipitation appears to be due to the orographic lift of the moist and impinging low-level flow. Consequently, the vertical uplifts forced by the Dinaric Alps area were favourable for convection initiation and maintenance. 
(a)

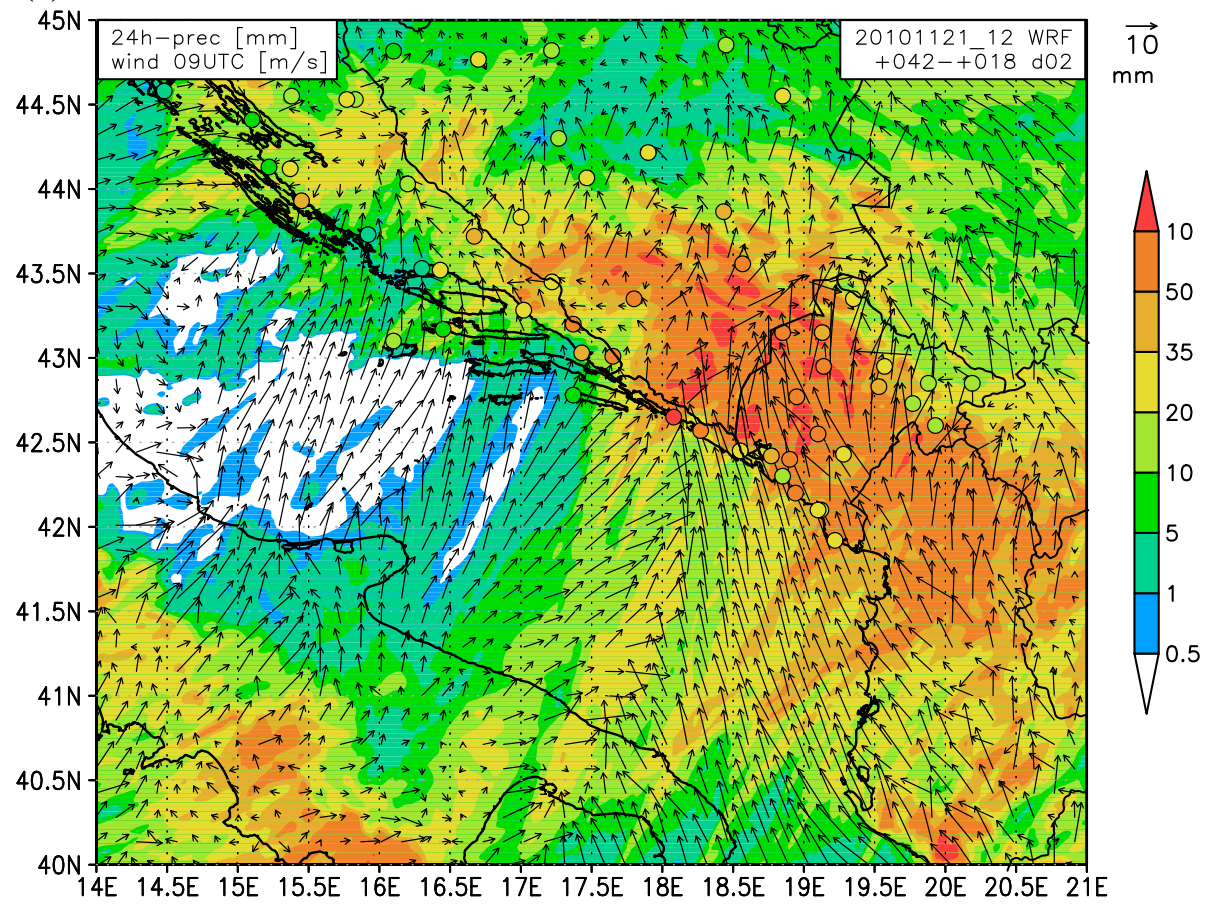

(b)

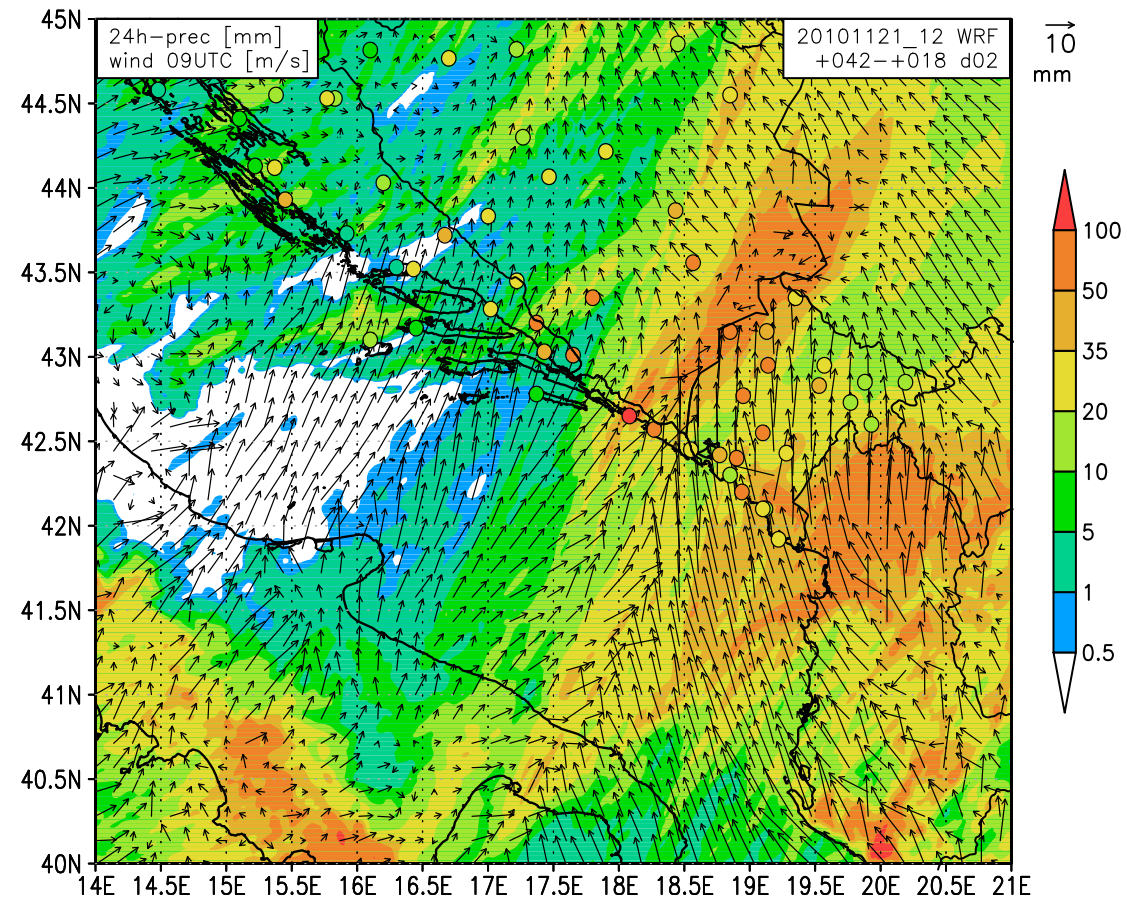


4Fig. 13 24-h observed (circle) and modelled precipitation (mm, shaded as in legend) from 22 to 23 November 2010 at 06 UTC and 10-m wind vectors at 09 UTC 22 November 2010: a simulation with orography, b simulation without orography. The area corresponds to the inner model domain (2-km grid spacing)

\section{Discussion and conclusions}

This paper is geographically focused on the southern Adriatic region, which is prone to relatively frequent HPEs that mostly occur in the autumn. This region, which lacks radar observation, has received little attention up to now. The aim of this study was to identify the main mesoscale features and mechanisms responsible for the HPEs in the southern Adriatic area as a contribution to the progress in the predictability of intense events, which could lead to better mitigation and adaptation measures for high-impact weather situations.

This study identified certain features responsible for the heavy rainfall that occurred during the morning hours on 22 November 2012 over the Dubrovnik coast and the hinterland mountain range of the southern Dinaric Alps. This event caused severe flash floods, landslides and interruption of traffic and electricity supply as well as other infrastructural damage.

Extreme value analysis of the precipitation maxima shows that the highest precipitation amounts in the longer-term intervals of $2-18 \mathrm{~h}$ exceeded the absolute annual maxima recorded since 1959 . Their return values range from approximately 70 years (for the 6-h maximum) to 160 years (for the 4-h maximum). The incorporation of recorded rainfall maxima in the calculations of project parameters for the drainage systems of the Dubrovnik urban and rural region would likely correct the existing project parameters for this area and ensure relevant values for the recent climate conditions of the short-term heavy precipitation.

The analysis of this HPE is based on the available observations and numerical outputs. The synoptic environment was characterised by a deep cut-off low moving from northern Europe over the Alps and the western Mediterranean, where surface cyclones developed. The associated frontal system covered most of the central Europe and the mid-Mediterranean. During the passage of the cold front over southern Italy and the Adriatic Sea, a secondary cyclone developed and a mesoscale convective system grew within. Advection of the warm air combined with intensive advection of cyclonic (positive) vorticity (as a consequence of the deepening trough in the neighbourhood of the left exit region of the jet streak) contributed to the strong upward motion in the area of the southern Adriatic and the adjacent mountains.

The HPE initiated in the area was characterised by a high CAPE. This study shares with Cohuet et al. (2011) the consideration that the dry layer above the thermal boundary could enhance the precipitation evaporation and hence the strengthening of downdrafts and cold outflow from convection.

The main mesoscale dynamical process for this HPE initiation and development was the low-level convergence directly generated by two LLJs, which carried warm and humid Mediterranean air to the Adriatic Sea. Mesoscale orographic perturbation in the area of Dinaric Alps provided conditions for mesoscale cyclonic generation and strengthening of local SE jugo wind gusts. A combination of the low-level convergence and the orographic effect led to severe precipitation along the south Adriatic coast in the area of Dubrovnik, the south of Montenegro and the adjacent mountain range (over $70 \mathrm{~mm} / \mathrm{h}$ ). Precipitation over the sea was less prominent, but still extreme with hourly rainfall rates above $20 \mathrm{~mm} / \mathrm{h}$ in certain periods, according to the satellite data. This result shows that in addition to the 
orographic lift, other mesoscale factors, i.e. the low-level (moisture) convergence, contributed to the measured precipitation maximum over the Dubrovnik area. This study identified certain similar features responsible for the heavy rainfall observed in other central Mediterranean heavy precipitation events (e.g. Mastrangelo et al. 2011).

Comparison of the modelled precipitation in the simulations with and without orography and with the measured and satellite-estimated precipitation leads to the conclusion that convergence-caused cloudiness and precipitation were additionally enhanced by the effect of orography.

Clearly, only one HPE is not sufficient for overly broad generalisation. Therefore, additional knowledge is needed to advance the predictability of intense precipitation events, in particular by improving the modelling of the processes that produce HPEs. Because the success of high-resolution modelling strongly depends on the initial conditions, introduction of additional observations, particularly radar data covering the Adriatic Sea, would greatly improve the high-resolution numerical weather prediction. Improving the ability to predict the location and the amount of heavy precipitation will have an impact on a wide range of human activities in this touristic area.

These scientific issues motivate the HyMeX (Hydrological cycle in the Mediterranean Experiment, http://www.hymex.org/) experimental programme, which is aimed at better quantification and understanding of the water cycle in the Mediterranean with emphasis on intense events. One of the major objectives of $\mathrm{HyMeX}$ is to understand the dynamics and improve the prediction of heavy precipitation over the Mediterranean region. The HPEs, which are usually associated with devastating flash floods, are the most ubiquitous hazardous weather phenomena in the Mediterranean region. The Adriatic Sea has been proposed as a target area in HyMeX for the study of heavy precipitation events and flash floods. Therefore, this study could contribute to the pre-studies carried out to prepare for future HyMeX field campaigns in the Adriatic target area.

Acknowledgments This work was supported by Grants 004-1193086-3036 and 004-1193086-3035 from the Ministry of Science, Education and Sports of the Republic of Croatia and is a contribution to the HyMeX programme. The authors thank the SAF NWC community, especially their colleagues from Spanish Meteorological Agency (AEMET), for providing the CRR data for the research. Martina Tudor is acknowledged for assistance in gathering the observational data presented in Fig. 13.

Open Access This article is distributed under the terms of the Creative Commons Attribution License which permits any use, distribution, and reproduction in any medium, provided the original author(s) and the source are credited.

\section{References}

Betts AK, Miller MJ (1986) A new convective adjustment scheme. Part II: single column tests using GATE wave, BOMEX, and arctic air-mass data sets. Q J R Meteorol Soc 112:693-709

Bougeault P, Binder P, Buzzi A, Dirks R, Houze R, Kuettner J, Smith RB, Steinacker R, Volkert H (2001) The MAP special observing period. Bull Am Meteorol Soc 82:433-462

Brzović N, Strelec Mahović N (1999) Cyclonic activity and severe jugo in the Adriatic. Phys Chem Earth (B) 6:653-657

Buzzi A, Foschini L (2000) Mesoscale meteorological features associate with heavy precipitation in the southern alpine region. Meteorol Atmos Phys 72:131-146

Buzzi A, Richard E, Romero R (2005) Summary report on MEDEX studies and scientific results on Mediterranean cyclones causing high impact weather. Report on scientific results. http://medex.aemet. uib.es/documents/Summary_on_MEDEX_studies_Nov05.pdf 
Campins J, Genoves A, Jansa A, Guijarro A, Ramis C (2000) A catalogue and a classification of surface cyclones for the Western Mediterranean. Int J Climatol 20:969-984

Campins A, Jansa A, Genoves A (2006) Three-dimensional structure of western Mediterranean cyclones. Int J Climatol 26:323-343

Carr FH, Millard JP (1985) Composite study of comma clouds and their association with severe weather over the Great Plains. Mon Weather Rev 113:370-387

Chen F, Dudhia J (2001) Coupling an advanced land surface-hydrology model with the Penn State-NCAR MM5 Modeling System. II: preliminary model validation. Mon. Wea. Rev. 129:587-604

Cohuet JB, Romero R, Homar V, Ducrocq V, Ramis C (2011) Initiation of a severe thunderstorm over the Mediterranean Sea. Atmos Res 100:603-620

Coles S (2001) An Introduction to statistical modelling of extreme values. Springer, London $208 \mathrm{pp}$

Crook NA, Klemp JB (2000) Lifting by convergence lines. J Atmos Sci 57:873-890

Doswell CA III, Ramis C, Romero R, Alonso S (1998) A diagnostic study of three heavy precipitation episodes in the western Mediterranean region. Weather Forecast 13:102-124

Ducić V, Luković J, Burić D, Stanojević G, Mustafić S (2012) Precipitation extremes in the wettest Mediterranean region (Krivošije) and associated atmospheric circulation types. Nat Hazards Earth Syst Sci 12:687-697. doi:10.5194/nhess-12-687-2012

Ducrocq V, Nuissier O, Ricard D, Lebeaupin C, Thouvenin T (2008) A numerical study of three catastrophic precipitating events over western Mediterranean region (southern France), Part II: mesoscale triggering and stationarity factors. Q J R Meteorol Soc 34:131-145

Dudhia J (1989) Numerical study of convection observed during the winter monsoon experiment using a mesoscale two-dimensional model. J Atmos Sci 46:3077-3107

Ek MB, Mitchell KE, Lin Y, Rogers E, Grummann P, Koren V, Gayno G, Tarpley JD (2003) Implementation of Noah land surface model advances in the National Centers for Environmental Prediction operational mesoscale Eta model. J Geophys Res 108(D22):8851

Faragó T, Katz RW (1990) Extremes and design values in climatology. World Meteorological Organisation, WMO-TD-No. 386, WCAP-No. 14, p 46

Frei C, Schär Ch (1998) A precipitation climatology of the Alps from high resolution rain-gauge observations. Int J Climatol 18:873-900

Gajić-Čapka M (2010) Precipitation over the broader Dubrovnik area (in Croatian). Hrvatske vode/Croatian waters, No. 74, pp 285-372

Gajić-Čapka M, Ivančan-Picek B (2000) Assessment of heavy rainfall. In: European conference on applied climatology ECAC2000, 16-20 Oct 2000, Pisa, Italy, Book of abstracts, 290, (CD ROM, Abs.Pos-7)

Grisogono B, Belušić D (2009) A review of recent advances in understanding the meso- and micro-scale properties of the severe bora wind. Tellus 61A:1-16

Horvath K, Lin Y-L, Ivančan-Picek B (2008) Classification of cyclone tracks over the Apennines and the Adriatic Sea. Mon Weather Rev 136:2210-2227

Isotta FA, Frei C, Weilguni V, Perčec Tadić M, Lassègues P, Rudolf B, Pavan V, Cacciamani C, Antolini G, Ratto SM, Munari M, Micheletti S, Bonati V, Lussana C, Ronchi C, Panettieri E, Marigo G, Vertačnik G (2013) The climate of daily precipitation in the Alps: development and analysis of a high-resolution grid dataset from pan-Alpine rain-gauge data. Int J Climatol. doi:10.1002/joc.3794

Ivančan-Picek B, Glasnović D, Jurčec V (2003) Analysis and ALADIN prediction of a heavy precipitation event on the Eastern side of the Alps during MAP IOP5. Meteorol Z 12:73-82

Ivatek-Šahdan S, Ivančan-Picek B (2006) Effects of different initial and boundary conditions in ALADIN/ HR simulations during MAP IOPs. Meteorol Z 15:187-197

Janjić ZI (1996) The surface layer in the NCEP Eta model. In: Eleventh conference on numerical weather prediction, Norfolk, VA, 19-23 Aug 1996, Amer. Meteor. Soc., Boston, MA, pp 354-355

Janjić ZI (2001) Nonsingular implementation of the Mellor-Yamada Level 2.5 scheme in the NCEP Meso Model. NCEP Office Note, No. 437, $61 \mathrm{pp}$

Jansa A, Alpert P, Buzzi A, Arbogast P (2001a) MEDEX, cyclones that produce high impact weather in the Mediterranean. http://medex.inm.uib.es

Jansa A, Genoves A, Picornell MA, Campins J, Riosalido R, Carretero O (2001b) Western Mediterranean cyclones and heavy rain. Part 2: statistical approach. Meteorol Appl 8(1):43-56. doi:10.1017/ S1350482701001049

Jenkinson AF (1969) Statistics of extremes, estimation of maximum floods. World Meteorological Organisation, Geneve, WMO Technical Note No. 98, Chapter 5

Johns RH, Doswell CA III (1992) Severe local storms forecasting. Weather Forecast 7:588-612

Jurčec V, Ivančan-Picek B, Tutiš V, Vukičević V (1996) Severe Adriatic jugo wind. Meteorol Z N F 5:67-75 
Kozarić T, Ivančan-Picek B (2006) Meteorological features of extreme precipitation in the Northern Adriatic. Croat Meteorol J 41:53-67

Maddox RA, Hoxit LR, Chappell CF (1980) A study of tornadic thunderstorm interactions with thermal boundaries. Mon Weather Rev 108:322-336

Magaš D (2002) Natural-geographic characteristics of the Boka Kotorska area as the basis of development. Geoadria 7(1):51-81

Mastrangelo D, Horvath K, Riccio A, Miglietta MM (2011) Mechanisms for convection development in a long-lasting heavy precipitation event over southeastern Italy. Atmos Res 100:586-602

Mellor GL, Yamada T (1974) A hierarchy of turbulence closure models for planetary boundary layers. J Atmos Sci 31:1791-1806

Mellor GL, Yamada T (1982) Development of a turbulence closure model for geophysical fluid problems. Rev Geophys Space Phys 20:851-875

Miglietta MM, Buzzi A (2001) A numerical study of moist stratified flows over isolated topography. Tellus 53A:481-499

Mikuš P, Telišman Prtenjak M, Strelec Mahović N (2012) Analysis of the convective activity and its synoptic background over Croatia. Atmos Res 104-105:139-153

Mlawer EJ, Taubman SJ, Brown PD, Iacono MJ, Clough SA (1997) Radiative transfer for inhomogeneous atmosphere: RRTM, a validated correlated-k model for the longwave. J Geophys Res 102(D14): $16663-16682$

Morrison H, Thompson G, Tatarskii V (2009) Impact of cloud microphysics on the development of trailing stratiform precipitation in a simulated squall line: comparison of one- and two-moment schemes. Mon Weather Rev 137:991-1007

Nuissier O, Ducrocq V, Ricard D, Lebeaupin C, Anquetin S (2008) A numerical study of three catastrophic precipitating events over Southern France I: numerical framework and synoptic ingredients. Q J R Meteorol Soc 134:111-130

Orlić M, Kuzmić M, Pasarić Z (1994) Response of the Adriatic Sae to the bora and sirocco forcing. Cont Shelf Res 14:91-116

Pasarić Z, Belušić D, Klaić ZB (2007) Orographic influences on the Adriatic sirocco wind. Ann Geophys 25:1263-1267

Romero R (2001) Sensitivity of a heavy-rain producing western Mediterranean cyclone to embedded potential-vorticity anomalies. Q J R Meteorol Soc 127:2559-2597

Romero R, Doswell CA, Ramis C (2000) Mesoscale numerical study of two cases of long-lived quasistationary convective systems over Eastern Spain. Mon Weather Rev 128:3731-3752

Schneider U, Becker A, Finger P, Meyer-Christoffer A, Ziese M, Rudolf B (2013) GPCC's new land surface precipitation climatology based on quality-controlled in situ data and its role in quantifying the global water cycle. Theor Appl Climatol. doi:10.1007/s00704-013-0860-X

Skamarock WC, Klemp JB, Dudhia J, Gill DO, Barker DM, Duda MG, Huang X-Y, Wang W, Powers JG (2008) Description of the advanced research WRF version 4, Rep. NCAR/TN-475++STR, National Center for Atmosphere Research, Boulder, CO

Trigo IF, Davies TD, Bigg GR (1999) Objective climatology of cyclones in the Mediterranean region. J Clim 12:1685-1696

Tudor M, Stanešić A, Mazzocco Drvar D, Plačko-Vršnak D, Ivatek-Šahdan S (2011a) Heavy rainfall and flash flood in Dubrovnik on 22 November 2010. 5th HyMeX workshop, 17-19 May 2011, Punta Prima, Menorca, Spain. http://www.hymex.org/?page=private/workshops/5/program

Tudor M, Stanešić A, Ivatek-Šahdan S, Horvath K (2011b) Severe convective precipitation at Pula on 25th September 2010: NWP model simulations. In: 6th European conference on severe storms (ECSS 2011), 3-7 Oct 2011, Palma de Mallorca, Balearic Islands, Spain. http://www.essl.org/ECSS/2011/ programme/abstracts/papers.html\#A141

Turato B, Reale O, Siccardi F (2004) Water vapor sources of the October 2000 Piedmont flood. J Hydrometeorol 5(4):693-712

Vrhovec T, Gregorič G, Rakovec J, Žagar M (2001) Observed versus forecasted precipitation in the South East Alps. Meteorol Z 10:17-27

WMO (2004) Report of the CCI/CLIVAR expert team on climate change detection, monitoring and indices (ETCCDMI), WCDMP, No 54

Zaninović K, Gajić-Čapka M, Perčec Tadić M, Vučetić M, Milković J, Bajić A, Cindrić K, Cvitan L, Katušin Z, Kaučić D, Likso T, Lončar E, Lončar Ž, Mihajlović D, Pandžić K, Patarčić M, Srnec L, Vučetić V (2008) Klimatski atlas Hrvatske/Climate atlas of Croatia 1961-1990, 1971-2000. Državni hidrometeorološki zavod/Meteorological and Hydrological Service, Zagreb 200 pp 